УДК 66.067

${ }^{[0000-0001-5287-3733]}$ Г. С. Столяренко ${ }^{1}$, д.m.н., профессор,

заведуюший кафедрой химических технологий и водоочистки, e-mail: radikal@ukr.net

Р. О. Азизов ${ }^{2}$, д.m.н., професcор,

e-mail: rustam.azizov57@gmail.com

Б. И. Тупицкий ${ }^{1}$, аспирант

e-mail: bogdan.tupitskiy@gmail.com

${ }^{1}$ Черкасский государственный технологический университет

б-р Шевченко, 460, г. Черкассы, 18006, Украина

${ }^{2}$ Таджикский технический университет имени М. Осими

\title{
ЭЛЕКТРОАКТИВАЦИОННАЯ ОЧИСТКА МИНЕРАЛИЗОВАННЫХ ВОД
}

В статье рассмотрены методы очистки подземных вод - их преимущества и недостатки. Проведено исследование эффективности методом электроактивации, а также определены зависимости параметров электрохимического воздействия на состав подземных вод. Получены графические зависимости степени очистки подземных вод от различных параметров (силы тока, напряжения, расстояния между электродами, времени проведения электроактивачии, объема отбора проб кислой воды в прочессе электроактивачии), проведен их анализ и сделаны выводы относительно использования процесса электрохимической активации для подготовки воды, подаваемой на стадию мембранного обессоливания.

Ключевые слова: предочистка морских вод, электроактивачия, степень очистки, очистка воды, проточный электроактиватор.

Постановка проблемы. Одной из главных проблем комплексной переработки морских вод является их высокая минерализация, а также минеральные и биологические отложения при деминерализации. Разработано несколько методов деминерализации вод: выпарка, реагентные, мембранные (обратный осмос), ионообменные, электродиализные и т.д.

Каждый из этих методов обладает как положительными, так и отрицательными качествами и применяется в определенных концентрационных пределах. Новые разработки предлагают комплексные многоступенчатые схемы очистки шахтных вод с переработкой концентрированных рассолов. Наиболее сложным узлом технологии извлечения солей является снижение содержания ионов $\mathrm{CO}_{3}{ }^{2-}, \quad \mathrm{SO}_{4}{ }^{2-}, \mathrm{Cl}^{-}$с 25000 до 1000 мг/дм ${ }^{3}$. Эти процессы весьма трудоемки и энергозатратны. Кроме того, такие методы, как электродиализ, обратный осмос, натрийкатионирование экономически целесообразно применять при минерализации $1000 \pm 100$ мг/дм ${ }^{3}$ и ниже. Таким образом, актуальной является задача создания аппарата первичной деминерализации высокоминерализованных шахтных вод с минимизацией энергетических затрат.

(C) Г. С. Столяренко, Р. О. Азизов, Б. И. Тупицкий, 2019 DOI: $10.24025 / 2306-4412.3 .2019 .178601$
К настоящему времени большинство научных и экспериментальных работ в области очистки минерализованных вод были направлены на первичное их очищение - осветление, обеззараживание, деминерализацию и нейтрализацию. Классификация методов следующая: механические, химические, физические, электрохимические и биологические методы.

Механические методы - это осветление, фильтрация, выделение твердой фазы под действием центробежных сил, сгущение осадков на центрифугах и вакуум-фильтрах. Они используются при предварительной очистке и освобождают воду только от механических примесей различной крупности (осветляют ее).

При химических методах очистки воды применяют реагенты для изменения химического состава загрязнителей или формы их нахождения в стоках (коагуляция, флокуляция, нейтрализация, обезвреживание (перевод ядовитых примесей в безвредные), обеззараживание, в том числе методом хлорирования, озонирования).

Биологические методы предназначены для очистки воды, содержащей загрязнения биогенного органического происхождения. В зависимости от типа микроорганизмов, уча- 
ствующих в переработке загрязнителей стоков, эти методы можно разделить на два вида: очистка воды аэробными и анаэробными методами.

Электрохимические методы. Для этого используют процессы анодного окисления и катодного восстановления, электрокоагуляции, электроактивации и электродиализа. Такие процессы протекают на электродах при пропускании через исходную воду постоянного электрического тока в электролизерах. В качестве электродов при этом используют графит или другие электролитически нерастворимые материалы.

Современный подход к решению проблемы охраны окружающей природной среды нацеливает на разработку безотходных (малоотходных) технологий, в том числе бессточных схем водоподготовки, утилизации образовавшихся отходов.

Реагентный метод - надежный. Но объемы подземных вод очень велики. Кроме того, недостатком реагентного метода является образование больших объемов отходов, в результате чего возникает потребность в свободной территории для размещения сборников шламов, а также необходимо постоянно контролировать дозирование реагентов.

Предлагается использовать доочистку вод на ионитах. Ионный обмен - эффективный метод обессоливания, но в ходе регенерации ионитов появляются еще более минерализованные регенерационные стоки.

Обратный осмос и электроосмос - потенциально наиболее выгодные методы, в связи с чем они наиболее применимы в технологии водоподготовки питьевой воды.

Таким образом, наибольший интерес сегодня представляют электрохимические и мембранные методы очистки минерализованных вод.

Состояние проблемы. Электрохимическая активация - это физико-химический процесс, совокупность электрохимического и электрофизического воздействия на воду в зоне пространственного разряда на поверхности электродов. При этом достигается неравновесное состояние в системе за счет переноса $\mathrm{H}^{+}$через границу «электролит 1 - мембрана электролит 2». Дополнительным преимуществом метода является направленное противодвижение ионов гидроксила. Ионы гидроксила, которые образовались на электроде при использовании проницаемых мембран, не ас- социируются с катионами водорода. При этом концентрация ионов $\mathrm{OH}^{-}$катодного раствора растет, что приводит к повышению $\mathrm{pH}$ до 1012. При этом достигается $70-80 \%$ выхода по току, например по снижению жесткости воды, катионов железа и других тяжелых металлов.

Таким образом, под воздействием свободных гидроксильных ионов протекают несколько конкурирующих реакций в катодной области:

$$
\begin{aligned}
& \mathrm{Ca}^{2+}+2 \mathrm{OH}^{-} \rightarrow \mathrm{Ca}(\mathrm{OH})_{2} \\
& 2 \mathrm{Ca}^{2+}+2 \mathrm{OH}^{-}+\mathrm{SO}_{4}^{2-} \rightarrow \mathrm{Ca}(\mathrm{OH})_{2} \mathrm{SO}_{4} \\
& \mathrm{OH}^{-}+\mathrm{HCO}_{3}^{-} \rightarrow \mathrm{CO}_{3}^{2-}+\mathrm{H}_{2} \mathrm{O} \\
& \mathrm{Ca}^{2+}+\mathrm{CO}_{3}^{2-} \rightarrow \mathrm{CaCO}_{3} \\
& \mathrm{Mg}^{2+}+2 \mathrm{OH}^{-} \rightarrow \mathrm{Mg}(\mathrm{OH})_{2} \\
& \mathrm{Fe}^{3+}+3 \mathrm{OH}^{-} \rightarrow \mathrm{Fe}(\mathrm{OH})_{3} .
\end{aligned}
$$

В анодной области присутствие иона хлора приводит к образованию ряда кислородсодержащих ионов хлора по известным механизмам электродных реакций:

$$
2 \mathrm{Cl}^{-}-2 e^{-}+\mathrm{H}_{2} \mathrm{O} \rightarrow 2 \mathrm{ClO}^{-}+2 \mathrm{H}^{+} .
$$

В связи с тем, что концентрация ионов $\mathrm{OH}^{-}$бесконечно мала, выход по реакции $6 \mathrm{Cl}^{-}+6 \mathrm{OH}^{-}-6 e \rightarrow 2 \mathrm{ClO}_{3}^{-}+4 \mathrm{Cl}^{-}+3 \mathrm{H}_{2} \mathrm{O}$ незначителен.

Так как в растворе хлорида натрия синтезируется ион гипохлорита, электрохимическая активация должна привести к обеззараживанию воды. Снижение концентрации органических соединений связано с адсорбцией и соосаждением на коллоидных частицах в катодной области и с частичным окислением растворенных органических веществ ионом гипохлорита на аноде, что упрощает технологию водоподготовки.

Цель работы. Исследование процесса деминерализации и обеззараживания и разработка аппарата комплексной очистки морской воды для окончательной деминерализации воды мембранными методами.

Таким образом, настоящая работа проводится с целью доказать, что данный метод очистки является универсальным методом предупреждения кальматации (сульфатных отложений), биообрастания и деминерализации, что может быть эффективным для технологии очистки воды при дальнейшем использовании обратноосмотических мембран. 
Преимущества метода - возможность использования метода под атмосферным давлением в присутствии органических соединений; замена полупроницаемых мембран на проницаемые; простота конструкции; возможность усовершенствования конструкции.

Научные результаты. Для лабораторных исследований использовали высокоминерализованную подземную воду (таблица 1), определили изначальный состав исходной воды, после чего провели ее очистку методом химической электроактивации (рисунок 1). Во время проведения опыта анализ воды осущест- вляли следующими методами: общую жесткость воды определяли комплексонометрическим методом согласно ГОСТ 4151-72; для определения хлоридов в исследуемой воде был применен аргентометрический метод определения по Мору в соответствии с ДСТУ ISO 9297:2007; сухой остаток определяли гравиметрическим методом по ГОСТ 18164-72; содержание сульфатов определяли турбидиметрическим методом согласно ГОСТ 4389-72 и определение $\mathrm{pH}$ проводилось потенциометрическим методом. Полученные данные были сведены в таблицу 1.

Таблица 1 - Результаты первичной очистки подземной воды методом электроактивации

\begin{tabular}{|l|c|c|c|}
\hline \multirow{2}{*}{$\begin{array}{c}\text { Паименование } \\
\text { потеля качества } \\
\text { воды }\end{array}$} & Исходная вода & $\begin{array}{c}\text { После очистки } \\
\text { методом } \\
\text { электроактивации }\end{array}$ & $\begin{array}{c}\text { Степень } \\
\text { очистки, \% }\end{array}$ \\
\hline Сухой остаток, мг/дм ${ }^{3}$ & 9806 & 4665 & 52,4 \\
\hline Сульфаты, мг/дм ${ }^{3}$ & 450 & 270 & 40 \\
\hline Хлориды, мг/дм ${ }^{3}$ & 2958 & 700 & 76,3 \\
\hline $\begin{array}{l}\text { Общая жесткость, } \\
\text { мг/дм }\end{array}$ & 43,8 & 20,5 & 53,2 \\
\hline
\end{tabular}

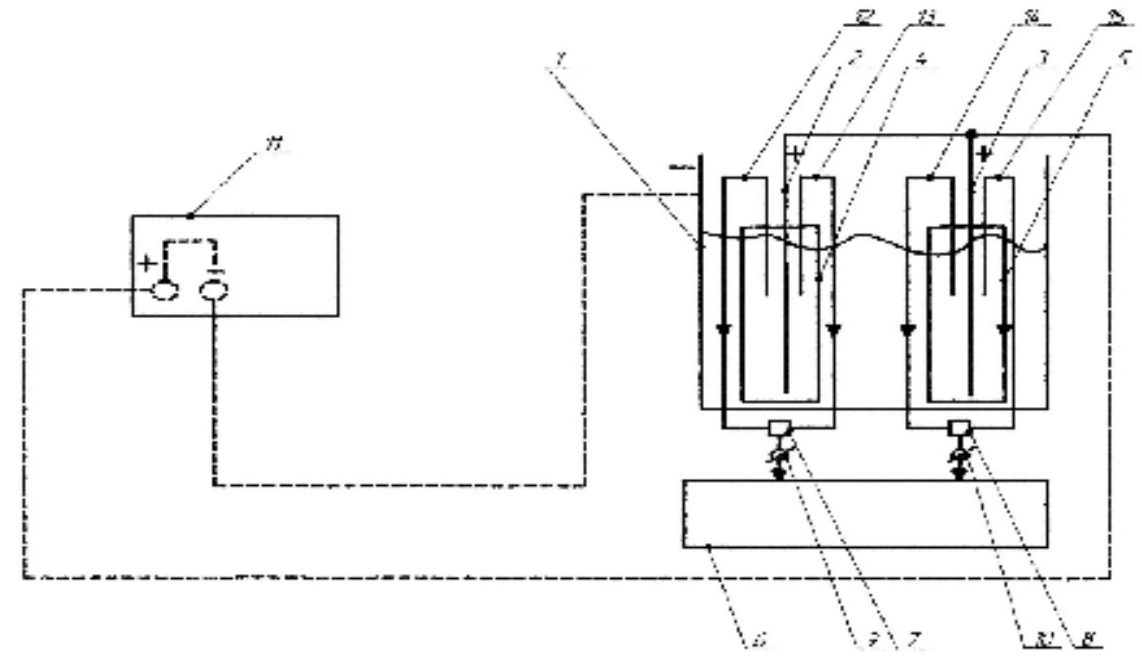

1 - корпус электроактиватора (катод); 2, 3 - электроды (аноды); 4, 5 - брезентовые мешки для электродов; 6 - емкость для анолита; 7, 8 - насосы; 9, 10 - краны для отбора анолита; 11 - блок питания; 12, 13, 14, 15 - патрубки для отбора анолита

\section{Рисунок 1 - Схема лабораторной установки для очистки воды методом электроактивации}

На рисунке 1 изображена лабораторная установка для очистки подземной воды методом электроактивации. Перед подачей исследуемой воды на установку ее предварительно профильтровали через бумажный фильтр для очистки от грубодисперсных взвешенных веществ.
В процессе химической электроактивации изменяли различные параметры: силу тока (I, A), напряжение (U, B), время (t, c), объем отбора кислой воды $\left(\mathrm{V}\right.$, дм$\left.^{3}\right)$, а также расстояние между электродами (L, мм). Результаты анализов отображены в графических зависимостях на рисунках 2-6. 
Исследование процесса деминерализации морской воды на стендовой установке. Исследуемые воды брали из Тилигульского лимана в Одесской области (таблица 2). Данный источник связан напрямую с источником воды для Одесского припортового завода, где используются мембранные технологии в схеме водоподготовки для производства. Экспери- ментальным путем установлены оптимальные условия электроактивации, определены изменения химических свойств морской воды после электроактивации, доказана целесообразность использования данного метода предочистки для устойчивой работы систем ультрафильтрации и обратного осмоса в течение длительного периода эксплуатации.

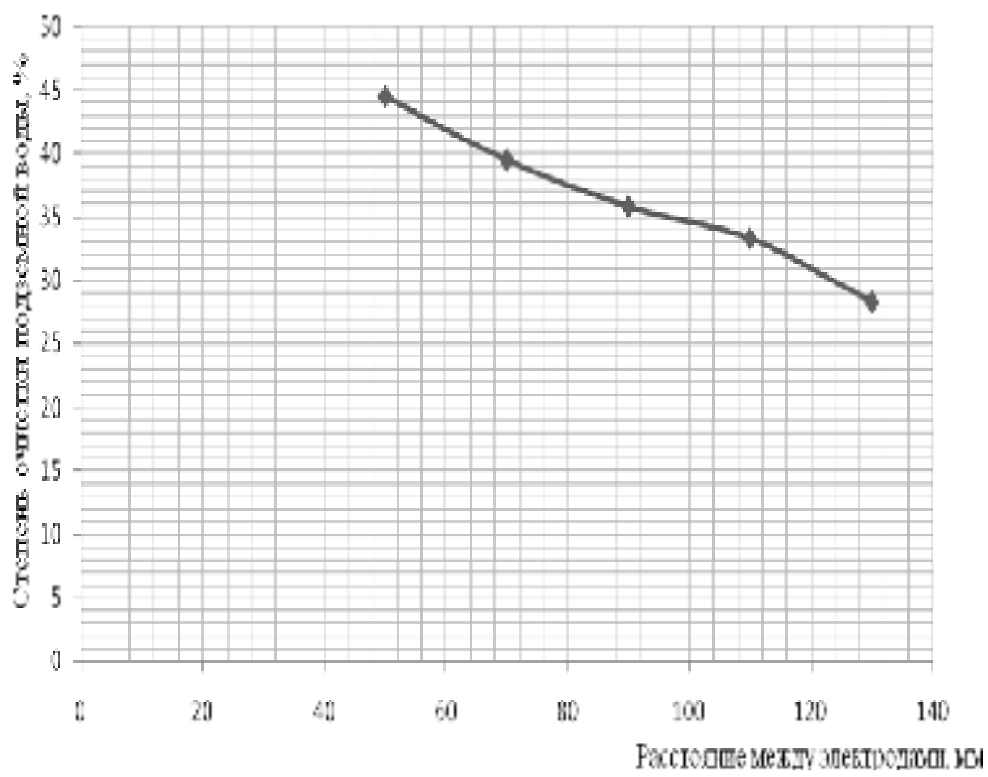

Рисунок 2 - График зависимости степени очистки подземных вод от расстояния между электродами в процессе электроактивации

$$
\begin{gathered}
y=a+b x+c x^{2}+d x^{3}+\ldots \\
y=30.859375+1.2952083 x+-0.033 x^{2}+0.00029791667 x^{3}+\ldots \\
e=-9.375 e^{-007}
\end{gathered}
$$

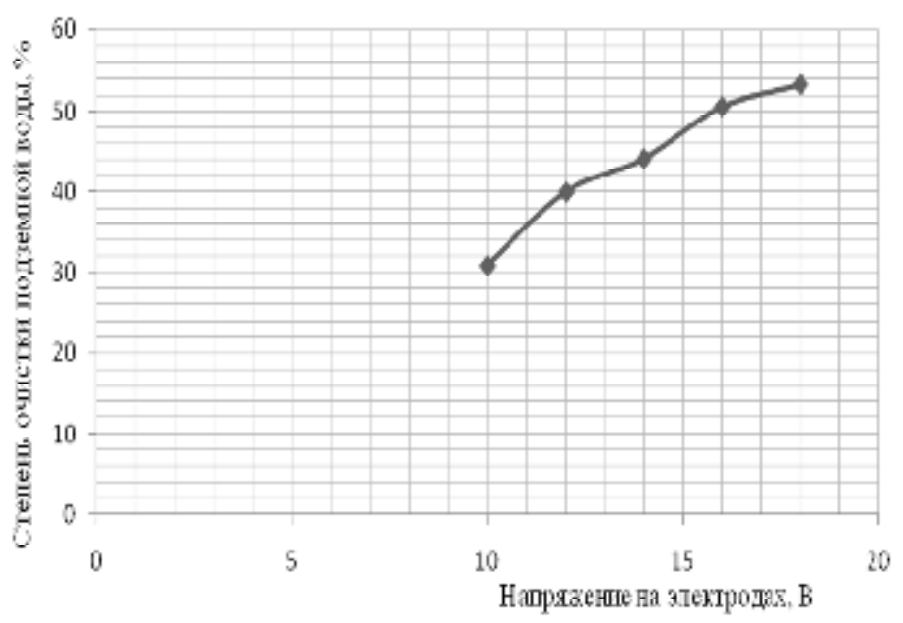

Рисунок 3 - График зависимости степени очистки подземных вод от напряжения в процессе электроактивации

$$
\begin{gathered}
y=a+b x+c x^{2}+d x^{3}+\ldots \\
y=-1246.7+370.04617 x+-39.927083 x^{2}+1.9083333 x^{3}+\ldots \\
e=-0.033854167 .
\end{gathered}
$$

(c) Г. С. Столяренко, Р. О. Азизов, Б. И. Тупицкий, 2019 DOI: $10.24025 / 2306-4412.3 .2019 .178601$ 


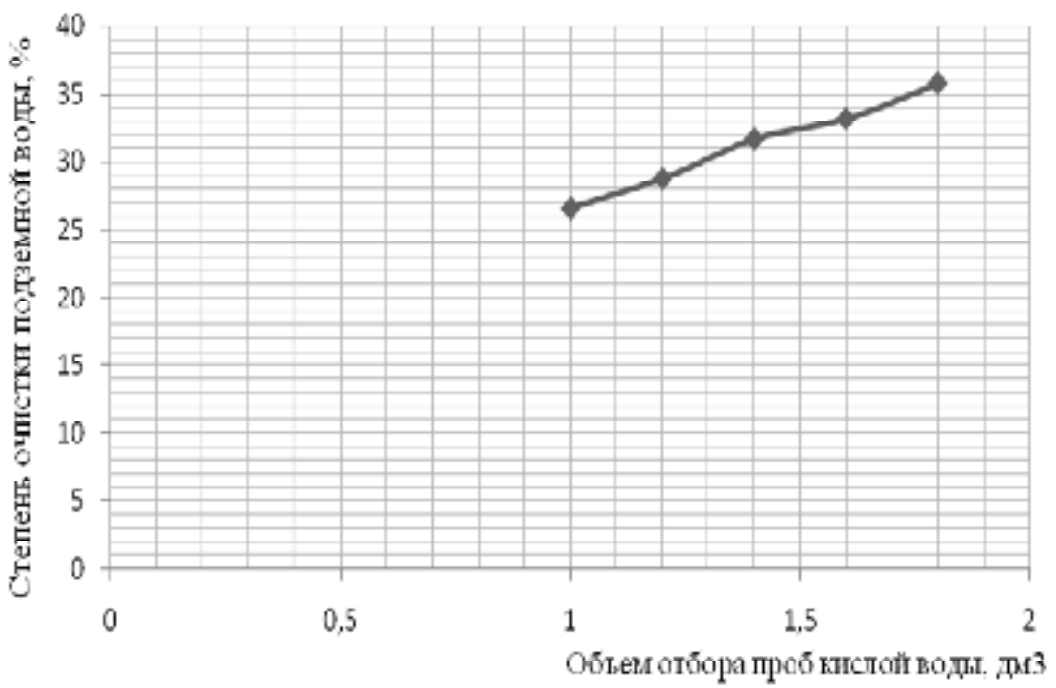

Рисунок 4 - График зависимости степени очистки подземных вод от объема отбора пробы кислой воды в процессе электроактивации

$$
\begin{gathered}
y=a+b x+c x^{2}+d x^{3}+\ldots \\
y=81.5+-0.38579167 x+0.0072239583 x^{2}+-5.6145833 e^{-007} x^{3}+\ldots \\
e=1.5885417 e^{-010}
\end{gathered}
$$

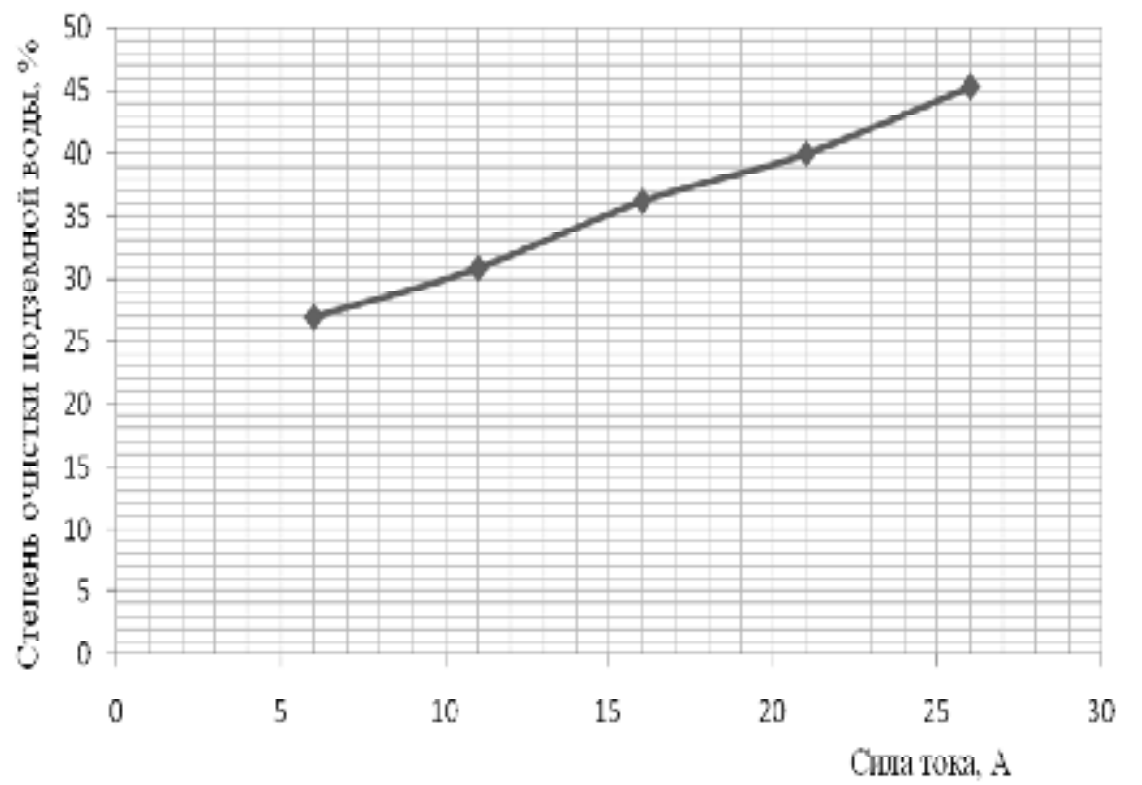

Рисунок 5 - График зависимости степени очистки подземных вод от силы тока в процессе электроактивации

$$
y=a+b x+c x^{2}+d x^{3}+\ldots
$$$$
y=421.6+-1217.0833 x+1368.9583 x^{2}+-666.66667 x^{3}+\ldots
$$$$
e=119.79167
$$ 


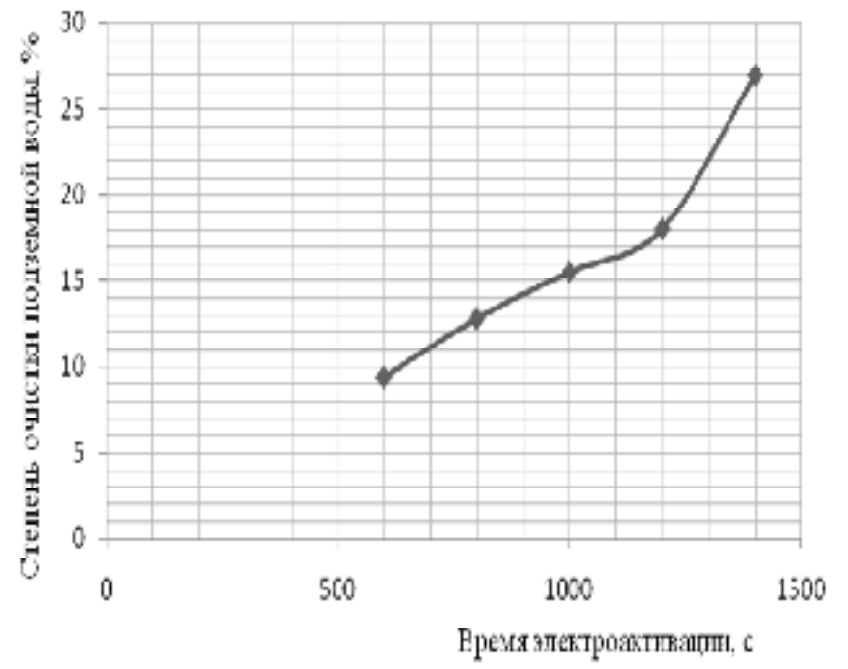

Рисунок 6 - График зависимости степени очистки подземных вод от времени проведения электроактивации

$$
\begin{gathered}
y=a+b x+c x^{2}+d x^{3}+\ldots \\
y=36.97376+-4.2101733 x+0.56112667 x^{2}+-0.025106667 x^{3}+\ldots \\
e=0.00039333333 .
\end{gathered}
$$

Таблица 2 - Состав воды из Тилигульского лимана Черного моря

\begin{tabular}{|c|c|c|}
\hline \multirow{2}{*}{ Катионы } & \multicolumn{2}{|c|}{ Содержание ионов } \\
\cline { 2 - 3 } & $\mathrm{B} \mathrm{мг/л}$ & В мг·экв/л \\
\hline $\mathrm{Ca}^{2+}$ & 370 & 18,463 \\
\hline $\mathrm{Mg}^{2+}$ & 715 & 58,848 \\
\hline $\mathrm{Na}^{+}$ & 2985 & 129,78 \\
\hline $\mathrm{K}^{+}$ & 730 & 18,67 \\
\hline Всего & 4800 & 225,76 \\
\hline Анионы & Содержание ионов \\
\hline & $\mathrm{B} \mathrm{мг/дм}$ & \\
\hline $\mathrm{Cl}^{-}$ & 868,77 & $\mathrm{~B}$ мг·экв/л \\
\hline $\mathrm{SO}_{4}{ }^{2-}$ & 1092 & 24,51 \\
\hline $\mathrm{HCO}_{3}^{-}$ & 341 & 22,75 \\
\hline $\mathrm{Bcего}$ & 2301,77 & 5,59 \\
\hline
\end{tabular}

Общая минерализация воды составляет несколько выше 7200 мг л, или 7,1 г/дм ${ }^{3} . \mathrm{pH}$ воды составляет 7,5. Для проведения исследований разработан аппарат непрерывного действия с электродами особой конструкции (стальные катоды и ОРТА-аноды), позволяющий перерабатывать $2 \mathrm{~m}^{3}$ воды в час. На морской воде выполнено более 50 серий опытов по деминерализации и обеззараживанию. При исследованиях намечены пути усовершенствования работы аппарата, оптимизации подвода электроэнергии, реконструкции электродов, что даст возможность получить более высокую степень деминерализации шахтных вод.
Содержание ионов $\mathrm{Ca}^{2+}$ и $\mathrm{Mg}^{2+}$ в процессе очистки морской воды уменьшается за один проход через электроактиватор в 2,5 раза; содержание сухого остатка - на $55 \%$; концентрация сульфат-ионов уменьшается в 2 раза; бикарбонат-ионов - на $85 \%$; концентрация железа и тяжелых металлов на 85-96\%; органических соединений - на 58-65 \%, микроорганизмов - на 89-94 \%. Остаточный активный хлор после смешения католита (с предварительным извлечением осадка) и анолита поддерживают в чистом виде, без кальматационных и биологических отложений, длительное время. 


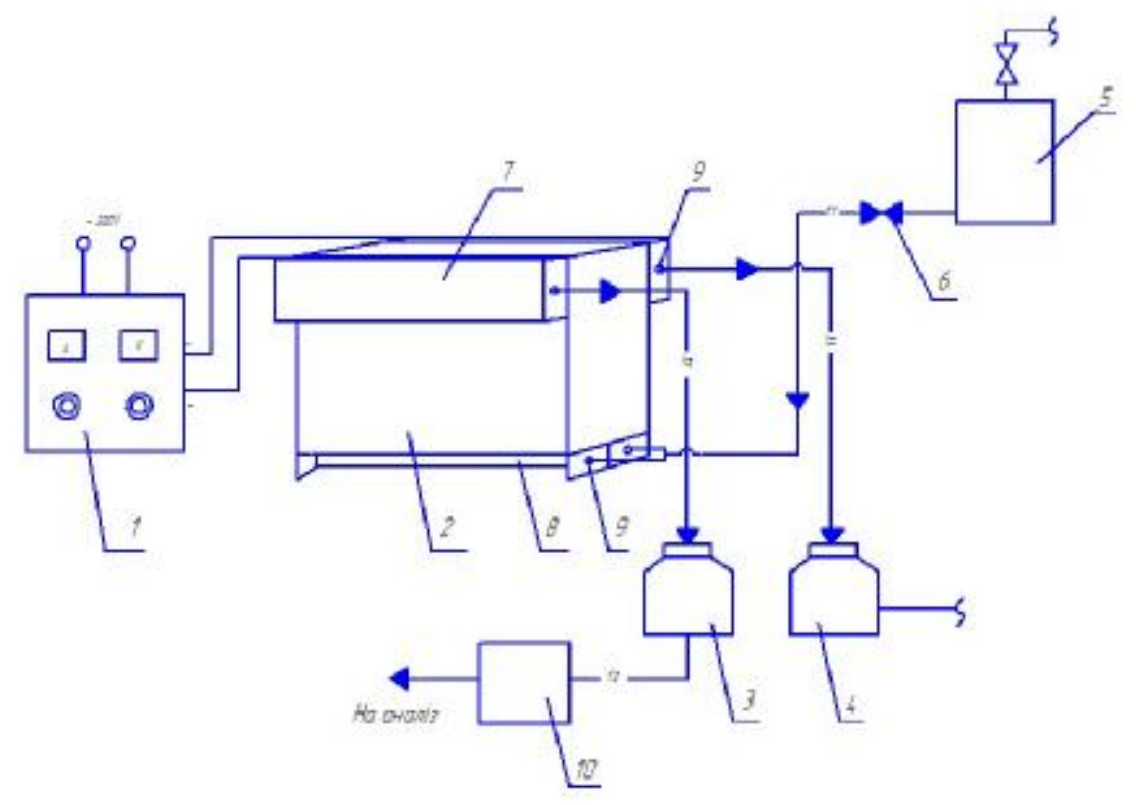

1 - блок питания; 2 - основная емкость; 3 - емкость для католита; 4 - емкость для анолита; 5 - емкость с исследуемой водой; 6 - кран; 7 - камера для отвода воды; 8 - камера для подвода воды; 9 - штуцер; 10 - отстойник анолита

\section{Рисунок 7 - Схема лабораторной установки электрохимической активации}

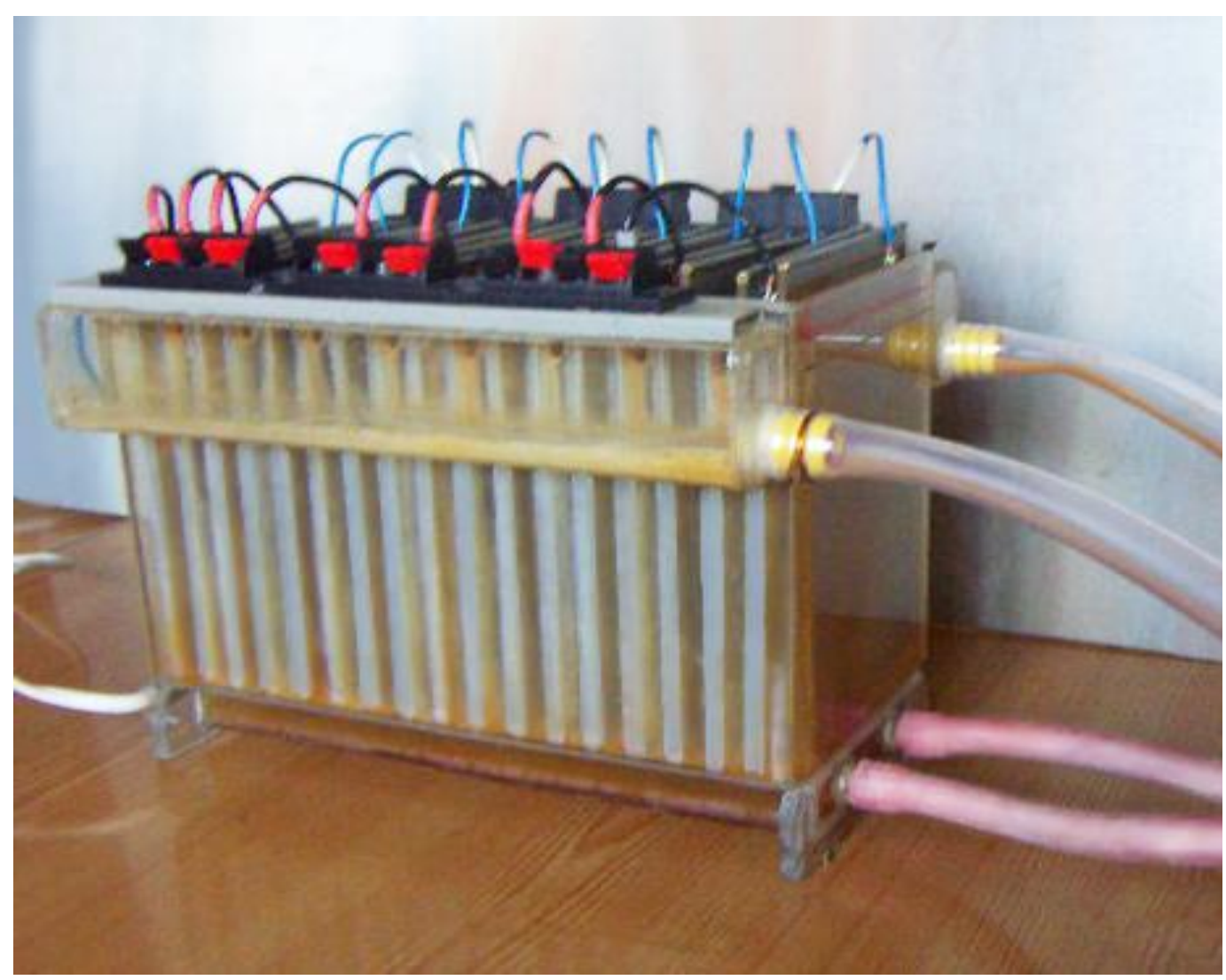

Рисунок 8 - Фото стендового электроактиватора проточного типа 
Комплексная очистка модельных растворов произведена при следующих технологических показателях: плотность тока $1,0-1,5 \mathrm{~A} /$ дм$^{2}$, количество электроэнергии по опытам (в кВт·ч/ $\left.\mathrm{M}^{3}\right)$ : № $1-5,5$, № $2-7,8$.

Таблица 3 - Степень очистки модельных растворов

\begin{tabular}{|c|c|c|c|}
\hline \multirow{2}{*}{ Показатели, мг/дм } & \multicolumn{3}{|c|}{ \% очистки } \\
\cline { 2 - 4 } & Исходные & Опыт 1 & Опыт 2 \\
\hline Солесодержание & 7228.6 & 50,64 & 59,39 \\
\hline Жесткость, мг-экв/дм ${ }^{3}$ & 77,31 & 67,21 & 74,15 \\
\hline Окисляемость, мг $\mathrm{O}_{2} /$ дм $^{3}$ & 14,0 & 78,40 & 80,10 \\
\hline Сульфаты & 1072,4 & 54,89 & 56,22 \\
\hline Хлориды & 867 & 58,61 & 58,99 \\
\hline Бикарбонаты & 341 & 81,60 & 87,00 \\
\hline $\mathrm{Ca}^{2+}$ & 370 & 69,50 & 70,45 \\
\hline $\mathrm{Mg}^{2+}$ & 715 & 58,12 & 60,11 \\
\hline $\mathrm{Fe}^{3+}$ & 2,5 & 96,2 & 98,4 \\
\hline
\end{tabular}

Расходы электроэнергии на деминерализацию и очистку воды составили $12-$ $14 \mathrm{\kappa Вт} \cdot 4 / \mathrm{m}^{3}$. Они являются суммой энергозатрат на транспортировку воды (28-30\%) и процесс электроактивации.

При использовании стадии электроактивации как стадии предварительной подготовки воды к процессу деминерализации на обратноосмотических мембранах в системе возможно снижение расходов электроэнергии на $15-20 \%$ за счет усовершенствования конструкции активатора.

\section{Выводы:}

1. Анализ полученных экспериментальных данных показал, что наибольшее влияние на показатель степени очистки оказывает повышение значения параметров напряжения и времени проведения электроактивации.

2. Электроактивационный химический метод очистки является универсальным методом предупреждения кальматации (сульфатных отложений), биообрастания и деминерализации, что может быть эффективным для технологии водоподготовки при дальнейшем использовании обратноосмотических мембран.

\section{Список литературы}

[1] И. С. Зекцер, Подземные воды как компонент окружающей среды. Москва: Научный мир, 2001. ISBN 5-89176-149-1.

[2] А. П. Пашков, "Екологічна безпека України", Безпека життєдіяльності, № 4, c. 10-16, 2011.

(C) Г. С. Столяренко, Р. О. Азизов, Б. И. Тупицкий, 2019 DOI: $10.24025 / 2306-4412.3 .2019 .178601$
[3] В. А. Горшков, Очистка и использование сточных вод предприятий угольной промылиленности. Москва: Недра, 1981.

[4] С. В. Яковлев, И. Г. Краснобородько, и В. М. Рогов, Технология электрохимической очистки воды. Ленинград: Стройиздат. Ленинг. отд-ние, 1987. ISBN 5-27400174-2.

[5] А. К. Запольський, Водопостачання, водовідведення та якість води. Київ: Вища школа, 2005. ISBN 966-642-234-4.

[6] В. М. Бахир, Электрохимическая активация: Изобретения, техника, технология. Москва: Делфин Аква, 2014. ISBN 978-5-9904688-3-2.

[7] K. Evan Nyer, Groundwater treatment technology. John Wiley \& Sons Inc, New York, United States, 2009. ISBN: 978-0471-65742-2.

[8] В. С. Алексеев, Г. М. Коммунар, и Н. В. Астрова, "Гидрогеологические проблемы регулирования качества подземных вод", Итоги науки и техники. Серия «Гидрогеология. Инженерная геология», c. 9-88, 1984.

[9] Nelson L. Nemerow, Franklin J. Agardy, Patrick Sullivan, and Joseph A. Salvato, Environmental engineering: water, wastewater, soil and groundwater treatment and remediation [Sixth Ed.]. John Wiley \& Sons, Inc. Hoboken, New Jersey, 2009. ISBN: 978-0-470-08303-1.

[10] В. М. Бахир, $\quad$ Ю. Г. Задорожний, Б. И. Леонов и др., Электрохимическая активачия: очистка воды и получение полезных растворов. Москва: ВНИИИМТ, 2001. 


\section{References}

[1] I. S. Zektser, Underground waters as an environment component. Moscow: Nauchnyj mir, 2001 [in Russian].

[2] A. P. Pashkov, "Ecological safety of Ukraine". Life Safety, no 4, pp. 10-16, 2011 [in Ukrainian].

[3] V. A. Horshkov, Wastewater treatment and utilization of coal industry enterprises. Moscow: Nedra, 1981 [in Russian].

[4] S. V. Yakovlev, Y. H. Krasnoborodko, and V. M. Rohov, Technology of electrochemical water treatment. Leningrad: Stroiyzdat, 1987 [in Russian].

[5] A. K. Zapolskyi, Water-supply, water disposal and water quality. Kyiv: Vyshcha shkola, 2005 [in Ukrainian].

[6] V. M. Bakhyr, Electrochemical activation: Inventions, technique, technology. Moscow: Delfin Aqua, 2014 [in Russian].
[7] K. Evan Nyer, Groundwater treatment technology. John Wiley \& Sons Inc, New York, United States, 2009.

[8] V. S. Alekseev, H. M. Kommunar, and N. V. Astrova, "Hydrogeological problems of groundwater quality control", The results of science and technology. Hydrogeology. Engineering geology, 1984 [in Russian].

[9] Nelson L. Nemerow, Franklin J. Agardy, Patrick Sullivan, and Joseph A. Salvato, Environmental engineering: water, wastewater, soil and groundwater treatment and remediation [Sixth Ed.]. John Wiley \& Sons, Inc. Hoboken, New Jersey, 2009.

[10] V. M. Bakhir, Yu. H. Zadorozhnyi, B. Y. Leonov, et al., Electrochemical activation: water purification and production of useful solutions. Moscow: VNIIIMT, 2001 [in Russian].

\author{
G. S. Stolyarenko ${ }^{1}$, R. O. Azizov $^{2}$, B. I. Tupitskiy ${ }^{1}$ \\ ${ }^{1}$ Cherkasy State Technological University, Ukraine \\ ${ }^{2}$ Tajik Technical University named after M. Osimi
}

\title{
ELECTROACTIVATED PURIFICATION OF MINERALIZED WATERS
}

One of the main problems of the integrated processing of sea, groundwater or mine water when receiving drinking water is their high salinity, as well as mineral and biological deposits in the processes of demineralization. Several methods for demineralization of water: evaporation, reagents, membranes (reverse osmosis), ion exchange, electrodialysis, etc. have been developed.

Each of these methods has both positive and negative qualities and is used within certain concentration limits. New developments offer complex multi-stage mine water treatment schemes with concentrated brine processing. The reduction of CO32-, SO42-, Cl-ions from 25000 to $1000 \mathrm{mg} / \mathrm{dm} 3$ is the most sophisticated component of salt extraction technology. These processes are very time consuming and energy intensive. In addition, methods such as electrodialysis, reverse osmosis, sodium cationization are economically feasible to apply with mineralization of 1000-100 $\mathrm{mg} / \mathrm{dm} 3$ and below. The urgent task is to create an apparatus for primary demineralization of highly mineralized mine water with minimization of energy costs.

The method of unipolar electrochemical activation in the purification and desalination of water provides a short-term state of the aqueous solution, when the cathode and anode electrolysis processes have changed its composition, and the processes of mutual neutralization of electrolysis products are artificially restrained by the presence of permeable membranes-partitions, which are temporarily electrodeparticles. At the cathode, a concentration gradient of hydroxyl ions is observed:

$2 \mathrm{H}_{2} \mathrm{O}+2 e \rightarrow 2 \mathrm{OH}+\mathrm{H}_{2}$.

At the anode acidification of the electrolyte occurs: $2 \mathrm{H}_{2} \mathrm{O}-4 e \rightarrow 2 \mathrm{H}++2 \mathrm{O}_{2}$.

In the cathode space, due to the increased concentration of free hydroxyl ions, secondary processes of fixation of hydroxides of a number of metals, the cations of which form OH-insoluble bases and basic salts, are observed.

The article deals with the methods of groundwater treatment - their advantages and disadvantages. The investigations carried out experimentally have proved the versatility of the method of electrochemical activation of water, which allows to reach the required desalination standards in 
one process, while reducing the content of organic compounds and (due to the synthesis of $\mathrm{ClO}^{-}$ions) to produce metered water chlorination. The catholyte and anolyte, after pre-extracting the precipitates formed, are mixed for another demineralization step (e.g. reverse osmosis).

It is found that the unipolar electrical activation method is effective for mineralized waters containing carbonates, sulfates and chlorides of calcium, magnesium, iron and other heavy metals. Chlorine ion, as shown by the experiments on the treatment of sodium chloride solution, leads to the formation of water desirable $\mathrm{ClO}$. and $\mathrm{ClO}_{3}^{-}$ions, which prevent the clogging and biofouling of membranes. Several semi-industrial devices have been developed and studies of the efficiency of the method of electroactivation have been carried out, dependences of parameters of electrochemical influence on the composition of highly mineralized and groundwater have been determined. Graphic dependences of the degree of water purification on various parameters (current, voltage, distance between electrodes, time of electro-activation, volume of acid water sampling during electroactivation) are obtained, their analysis is made and conclusions are drawn regarding the use of electrochemical activation process for the preparation of water supplied to stage of membrane desalting.

Keywords: seawater pretreatment, electroactivation, purification degree, water purification, flowing electroactivator.

\section{Г. С. Столяренко, Р. О. Азізов, Б. І. Тупицький}

\section{ЕЛЕКТРОАКТИВАЦІЙНЕ ОЧИЩЕННЯ МІНЕРАЛІЗОВАНИХ ВОД}

Однією з головних проблем інтегрованої обробки морських, підземних або шахтних вод при отриманні питної води є їх висока солоність, а також мінеральні та біологічні відкладення, щуо викликає труднощі в процесах демінералізащії. Актуальним завданням є створення апарату для первинної демінералізачії високомінералізованої води з мінімізацією енергетичних витрат. У статті розглядаються методи очищення підземних вод - їх переваги та недоліки. Метод однополярної електрохімічної активачії при очищенні та опрісненні води забезпечує короткочасний стан водного розчину, коли катодні та анодні прочеси електролізу змінили свій склад, а прочеси взаємної нейтралізації продуктів електролізу штучно стримуються через наявність проникних мембран-перегородок. Дослідження, проведені експериментально, довели універсальність методу електрохімічної активаиії води, щяо дозволяє досягти необхідних стандартів опріснення за один процес, зменшуючи при иьому вміст органічних сполук $i$ (завдяки синтезу йонів $\mathrm{ClO}^{-}$) отримувати дозоване хлорування води. Після попереднього вилучення утворених осадів католіт та аноліт змішують для ще однієї стадії демінералізації (наприклад, зворотного осмосу). Встановлено, що однополярний метод електричної активації ефективний для мінералізованих вод, щзо містять карбонати, сульфати та хлориди кальцію, магнію, заліза та інших важких металів. Йон хлору, як показали експерименти з обробки розчину хлориду натрію, приводить до утворення в воді бажаних для технології йонів $\mathrm{ClO}^{-}$та $\mathrm{ClO}_{3}^{-}$, які запобігають засміченню та біологічній обробиі мембран. Розроблено кілька напівпромислових приладів; проведено дослідження ефективності методу електроактивачї;; визначено залежності параметрів електрохімічного впливу на склад високомінералізованих та підземних вод. Аналіз отриманих експериментальних даних показав, що найбільший вплив на показник ступеня очищення має значення параметрів напруги і тривалості проведення електроактиваиіï. Електроактивачійний метод очищення сприяє попередженню кальматаиії (сульфатних відкладень) і біообростання, що може бути еффективним для технології водопідготовки при подальшому використанні зворотноосмотичних мембран.

Ключові слова: передочищення води, електроактивачія, ступінь очищення, очищення води, проточний електроактиватор.

Стаття надійшла 19.08.2019

Прийнято 07.09.2019

(C) Г. С. Столяренко, Р. О. Азизов, Б. И. Тупицкий, 2019 DOI: 10.24025/2306-4412.3.2019.178601 